\title{
Fine spore structure of a haplosporidan parasitizing Crassostrea gigas: taxonomic implications
}

\author{
Michel Comps, Yves Pichot \\ IFREMER, GIE-RA, Chemin de Maguelone, F-34250 Palavas-les-Flots, France
}

\begin{abstract}
Several cases of haplosporidan infection have been detected recently in Pacific oysters Crassostrea gigas from Etang de Thau, France. The ultrastructure of the spore, including the surface ornamentation, is described and appears similar to that of Haplosporidium costale. The taxonomic implications of these findings are discussed.
\end{abstract}

\section{INTRODUCTION}

The presence of haplosporidans in Crassostrea gigas was first reported by Katkansky \& Warner (1970) in Pacific oysters from Humboldt Bay, California, USA. Later, Kern (1976) described several cases of haplosporidan infections in C. gigas from the Chung Mu area of the Republic of Korea. In both papers, the authors referred to the morphological similarities of the organisms observed to those of Minchinia nelsoni. However, the lack of ultrastructural examination in their studies has prevented complete classification of these sporozoans.

Routine examinations of Pacific oysters from Etang de Thau, France, have revealed occasional new haplosporidan infections ( 2 cases in 1988; 1 case in 1989). In these cases, the infected oysters were very heavily parasitized by the organism. Upon gross examination, the parasitized oysters appeared abnormally grey in color and emaciated. No abnormal mortalities were observed at the sites where oysters were sampled.

This communication reports on ultrastructural studies of the sporulation of the haplosporidan organism, which were undertaken to define the precise developmental stages of spore development and the fine structure of the mature spore.

\section{MATERIAL AND METHODS}

Two-year-old Pacific oysters, maintained in suspended culture, were sampled from 12 stations at
Etang de Thau. Parasitized oysters ( 3 specimens) could be selected on gross examination by their more flattened valves and direct microscopic examination of fresh tissue squashes containing haplosporidan spores (Fig. 1e). For electron microscopic study, the tissues were fixed in a $3 \%$ solution of glutaraldehyde in seawater buffered with $0.4 \mathrm{M}$ sodium cacodylate, and postfixed in $2 \%$ osmium tetroxide before embedding in araldite resin (Polaron). Thin sections were stained with uranyl acetate and with lead citrate according to Reynolds (1963).

\section{RESULTS}

Various stages in the development of the parasite could be observed in connective tissues. The earliest stage of development observed was multinucleated polymorphic plasmodia, 2 to $12 \mu \mathrm{m}$ in size, containing large paraspherical haplosporosomes measuring 250 to $320 \mathrm{~nm}$ in diameter (Fig. 1a). The size of the plasmodia increased proportionally to the multiplication rate of the nuclei. The sporocysts formed were approximately spherical and ranged from 10 to $20 \mu \mathrm{m}$ in diameter. Each sporocyst contained about 5 to 25 ovoid spores, measuring $4.8 \mu \mathrm{m}( \pm 0.2 \mu \mathrm{m})$ in length and $3.4 \mu \mathrm{m}( \pm$ $0.2 \mu \mathrm{m}$ ) in width, in fixed tissues (Fig. 1b).

The immature spore was surrounded by an anucleate extrasporal cytoplasmic layer, 0.2 to $0.3 \mu \mathrm{m}$ thick (Fig 1b). This epispore cytoplasm contained ribbon-like elements ranging from 120 to $150 \mathrm{~nm}$ in width and showing a periodical substructure (periodicity of $12 \mathrm{~nm}$ ) (Fig 

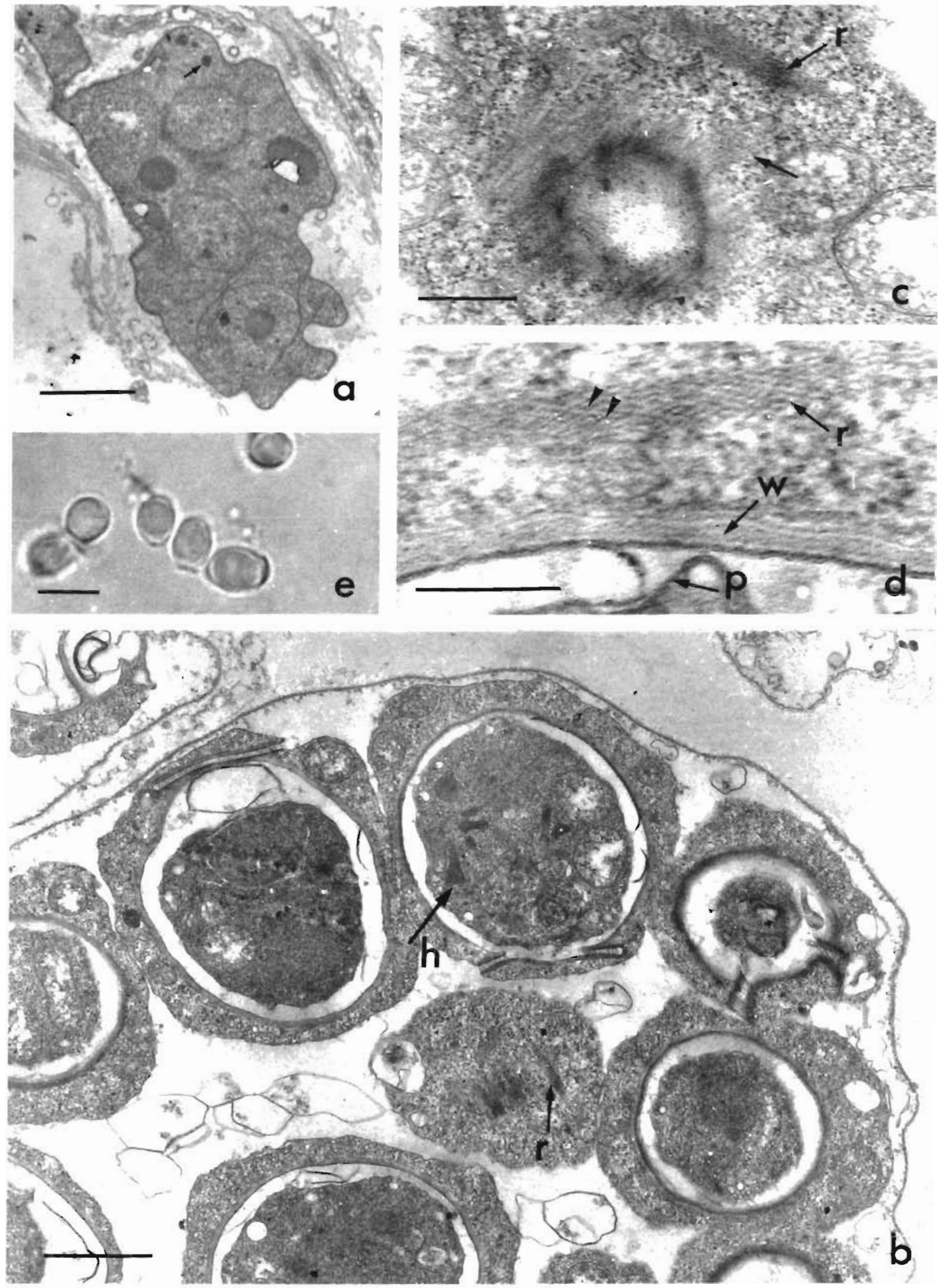

Fig. 1. Haplosporidian parasitizing Crassostrea gigas. (a) Multinucleated plasmodium at the early stage of sporulation; spherical haplosporosomes (arrow) are contained in the cytoplasm. EM; bar $=2 \mathrm{um}$. (b) Sporocyst containing immature spores exhibiting rod-shaped and cuneiform haplosporosomes (h) and ribbons ( $\mathrm{r}$ ) located in extrasporal cytoplasm. EM; bar $=1 \mu \mathrm{m}$. (c) Tangential section of immature spore showing substructural elements of outer layer of the wall (arrow) and intracytoplasmic ribbons (r). $E M ;$ bar $=300 \mathrm{~nm}$. (d) Section through extrasporal cytoplasm; ribbon $(r)$ appears periodically structured. $w$ : wall: $p$ : plasmalemma of the sporoplasm. EM; bar $=300 \mathrm{~nm}$. (e) Light micrograph of mature spores released in seawater. Bar $=5 \mu \mathrm{m}$ 

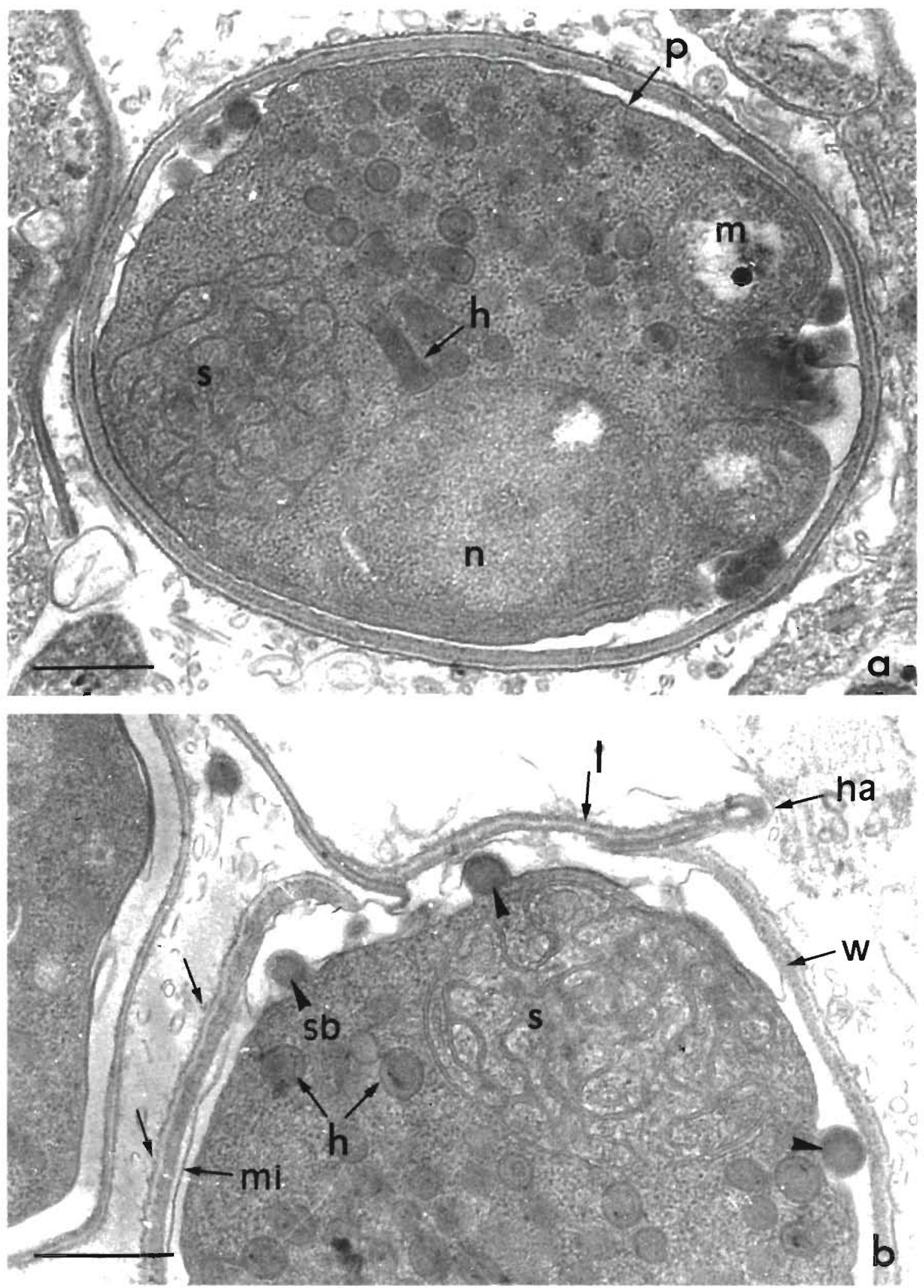

Fig. 2. Haplosporidian parasitizing Crassostrea gigas. Electron micrograph of sagittal sections through mature spores. (a) Morphology of the sporoplasm. n: nucleus; $\mathrm{m}$ : mitochondrion; h: haplosporosomes; $\mathrm{s}$ : spherule; $\mathrm{p}$ : plasmalemma. Bar $=500 \mathrm{~nm}$. (b) Hinge-like apparatus (ha) consisting of a continuity area between wall (w) and lid (l). Note electron-dense spherical bodies (sb) budding through the endosporoplasm membrane. In cross section, the haplosporosomes (h) clearly exhibit a bipartite structure (cotex and medulla). The 3-layered spore wall ( $w$ ) is internally covered by a membrane (mi). When the extrasporoplasm is degenerated, ribbon-like elements (arrows) are seen in surface of the outermost layer of spore wall. Bar $=500 \mathrm{~nm}$ 
1d). The spore wall did not exhibit ornamentation or filaments; however, tangential sections of the spore showed tubular ribs on its surface, each ca $60 \mathrm{~nm}$ in diameter (Fig. 1c). After lysis of the anucleate cytoplasm, some of these structures were still detectable, more or less associated with the outer electron-dense layer of the spore wall (Fig. 1a).

In mature spores, the spore wall had an average thickness of $160 \mathrm{~nm}$ and a tripartite structure. Completing the envelope of the sporoplasm, the spore lid appeared hinged to the wall in one defined sector (Fig. 2b).

The sporoplasm conformed to the morphological characters of the family Haplosporididae. The sporoplasm was limited by a single unit membrane. It contained a round nucleus (ca $1.5 \mu \mathrm{m}$ in diameter) and a typical spherule at the anterior pole (Fig. 2a).

Within the cytoplasm were large spherical mitochondria and rod-shaped haplosporosome-like electrondense bodies, about $300 \mathrm{~nm}$ in length, and $120 \mathrm{~nm}$ in diameter. Electron-dense lipid-like inclusions appeared to bud in the space between the wall and plasmalemma of the sporoplasm (Fig. 2b).

\section{DISCUSSION}

Based on the studies of Ormieres (1980), the absence of wall filaments should place this haplosporidan within the genus Minchinia (Labbé). The present tendency, after numerous taxonomic changes (Sprague 1963, Andrews 1966, Perkins 1969, Ormières 1980), is to place within the genus Minchinia only those species that have spore extensions visible under light microscopic examination (Perkins 1988). Accordingly, this haplosporidan parasite of Crassostrea gigas could be included in the genus Haplosporidium.

Compared with other members of the genus Haplosporidium, especially the marine species that parasitize bivalve molluscs, this species shows significant differences in size and fine structure of its spore. Important resemblances, however, are noted when the organism is compared to Haplosporidium costale, a parasite of the American oyster Crassostrea virginica. The latter also localizes in the connective tissue and has similar morphological features, including the paraspherical shape and ribbon-like ornamentations. The wallribbon ornamentation of Minchinia costale ( $H$. costale) has been described by Perkins (1969) and Rosenfield et al. (1969). The periodicity of the ribbon substructures of the haplosporidan described in this paper was estimated to ca $12 \mathrm{~nm}$, close to that of $H$. costale. Comparing the structure of the hinge of the lid between the 2 haplosporidans revealed no significant differences.

The organelles found in the sporoplasm do not differ from those described as Haplosporidium costale. The rod-shaped electron-dense bodies (haplosporosomes) with one flattened end have an identical morphology to the homologous bodies found in the sporoplasm of $H$. costale as described by Perkins (1969) as rod-like electron-dense structures, or as electron-dense bodies (SDV), in the work of Rosenfield et al. (1969).

Another common characteristic is the presence of electron-dense bodies in the space between the plasmalemma of the sporoplasm in the mature spore. Such inclusions cannot however be considered as specific identifiable differential structures since similar elements have been found in Haplosporidium lusitanicum (Minchinia Iusitanica after Perkins 1988) by Azevedo (1984)

The size of the sporocysts $(10$ to $15 \mu \mathrm{m})$ and the number of spores which they contain (5 to 25 ) are very similar in both parasites. On the other hand, the size of the spores appears to be the only element that distinguishes these 2 haplosporidans from each other. The spore of the haplosporidan that parasitizes Crassostrea gigas is larger than that of $H$. costale $(4.2 \times 3.1 \mu \mathrm{m}$ as compared to $3.1 \times 2.6 \mu \mathrm{m})$. Moreover, these measurements conform to the description of the spore of the haplosporidan infecting $C$. gigas in Humboldt Bay (Katkansky \& Warner 1970). If, like Perkins \& van Banning (1981), we consider that the size of the spore can vary with the host species involved and the site, the parasite observed in the oysters of Etang de Thau is consistent with $H$. costale.

Under these conditions, the Pacific oyster should be considered as a possible host for 2 important haplosporidan parasites of Crassostrea virginica, Haplosporidium costale and $H$. nelsoni. The haplosporidan observed in C. gigas from Korea by Kern (1976) cannot be differentiated from Minchinia nelsoni (H. nelsoni). Undoubtedly, serological studies could help in differentiating the identity and relative taxonomic positions of the parasites.

Acknowledgement. We thank Louis Leibovitz, Laboratory for Marine Animal Health, Marine Biological Laboratory, Woods Hole, Massachusetts, USA, for his help in reviewing the manuscript

\section{LITERATURE CITED}

Andrews, J. D. (1966). Oyster mortality studies in Virginia. V Epizootiology of MSX, a protistan pathogen of oysters. Ecology 47: 19-31

Azevedo, C. (1984). Ultrastructure of the spore of Haplosporidium lusitanicum (Haplosporida, Haplosporididae), parasite of a marine mollusc. J. Parasitol. 70: 358-371

Katkansky, S. C., Warner, R. W. \{1970\}. Sporulation of a haplosponidian in an Pacific oyster (Crassostrea gigas) in Humboldt Bay, California. J. Fish. Res. Bd Can. 27: $1320-1321$

Kern, F. G. (1976). Sporulation of Minchinia sp. (Haplosporida, 
Haplosporidiidae) in the Pacific oyster Crassostrea gigas (Thunberg) from the Republic of Korea. J. Protozool. 23: $498-500$

Ormières, R. (1980). Haplosporidium parisi n. sp., haplosporidie parasite de Serpula vermicularis L. Etude de la spore. Protistologica 16 (3): 467-474

Perkins, F. O. (1969). Electron microscope studies of sporulation in the oyster pathogen, Minchinia costalis (Sporozoa: Haplosporida). J. Parasitol. 55 (5): 897-920

Perkins, F. O. (1988). Structure of protistan parasites found in bivalve molluscs. Am. Fish. Soc. Spec. Publ. 18: 93-111

Perkins, F. O., van Banning, P. (1981). Surface ultrastructure

Responsible Subject Editor: A. K. Sparks, Seattle, Washing. ton, USA of spores in three genera of Balanosporida. J. Parasitol. 67 866-874

Reynolds, E. S. (1963). The use of lead citrate at high $\mathrm{pH}$ as an electron-opaque stain in electron microscopy. J. Cell Biol 17: $208-212$

Rosenfield, A., Buchanan, L., Chapman, G. B. (1969). Comparison of the fine structure of spores of three species of Minchinia (Haplosporida, Haplosporidiidae). J. Parasitol. 55 (5): $921-941$

Sprague, V. (1963). Revision of genus Haplosporidium and restoration of genus Minchinia (Haplosporidia, Haplosporidiidae). J. Protozool. 10 (3): 263-266

Manuscript first received: October 22, 1990

Revised version accepted: March 14, 1991 